Maria Jolanta Olszewska ${ }^{1}$

Uniwersytet Warszawski

DOI: https://doi.org/10.26881/jsr.2020.15.06

\title{
W BLASKU LEGENDY, CZYLI OGNISTY WÓZ ZOFII KOSSAK. LEKTURA W KONTEKŚCIE TWÓRCZOŚCI PISARKI
}

\author{
Ty się odważ świętym być! \\ A ty się odważ \\ (Cyprian Kamil Norwid)
}

Na marginesie twórczości Zofii Kossak sytuuje się tom mniej znanych opowiadań pt. Ognisty wóz, wydany w 1963 r. przez PAX, opatrzony pięknymi ilustracjami Danuty Rewkiewicz-Niemirskiej. Składa się na niego siedem krótkich opowiadań: Widzę go!, Ognisty wóz, Mędrcy świata, Stupnik i kusiciel, Legenda o św. Mikołaju z Pierśca, Naglace wołanie oraz Noc i świt. Teksty te, choć traktują o wydarzeniach rozgrywających się w różnym czasie - od ok. XIII w. p.n.e. (czyli od powrotu Izraelitów do Kaananu), przez moment narodzin Chrystusa i wydarzenia z V w. n.e., aż po czas okupacji niemieckiej w 1941 r. i październik 1944 r. (kiedy to ze zrujnowanej po powstaniu, wyniszczonej, zamienionej w pustynię Warszawy zostają wypędzeni jej mieszkańcy) - tworzą spójną myślowo i artystycznie całość. Są to krótkie formy narracyjne - miniatury, zaskakujące odbiorcę swą kunsztownością, genologicznie pokrewne noweli, obrazkowi lub krótkiemu opowiadaniu. Fabuła tych tekstów jest prosta, skupiona wokół jednego ważnego zdarzenia, co przekłada się na jednowątkową kompozycję, brak dygresji i zakończenie opatrzone wyrazistą pointą. Zamierzona krótkość wypowiedzi posłużyła kondensacji treści dotyczącej spraw o charakterze pierwszorzędnym: budowania relacji człowieka ze Stwórcą. Nadrzędnym tematem staje się w nich kwestia wiary w Boga w sytuacji ostatecznej: uwikłania w winę, walkę, cierpienie i śmierć.

Ognisty wóz wpisuje się dobrze w biblijne i apokryficzne konteksty pisarstwa Z. Kossak. Potwierdza, że to legenda jest tym właściwym fundamentem i spoiwem jej twórczości. Opowiadania z tomu Ognisty wóz tematycznie i myślowo nie

\footnotetext{
${ }^{1}$ mj.olszewska@uw.edu.pl,https://orcid.org/0000-0001-6230-0621
} 
odbiegają od innych utworów Z. Kossak. Tom ten zamyka, rzec można, całość dokonań twórczych pisarki, opartą na fundamencie religii chrześcijańskiej w duchu humanizmu chrześcijańskiego ${ }^{2}$. $Z$ tego powodu warto prześledzić wcześniejsze wątki obecne w pisarstwie Z. Kossak - po to, aby pokazać sposób, w jaki realizowane są one w ostatnim jej dziele. Pisarstwo Z. Kossak okazuje się niezwykle spójne od strony myślowej i artystycznej. Wyrasta „z trzech żywiołów: historycznego, patriotycznego i religijnego" (Kossak 2004, s. 18). W strukturze utworów wzajemnie determinują się różne gatunki, podporządkowane określonej wizji historii. Pisarce obcy był relatywizm historycznego poznania, daleka była ona od wszelkich form eksperymentowania, jak również prowadzenia gry z czytelnikiem. Historię postrzegała jako przestrzeń działania Opatrzności, gdzie nic nie dzieje się bez woli Boga, ponieważ całość dziejów została wpisana w Boski plan, którego celem jest Paruzja. Z. Kossak w szeregu swych powieści historycznych, wyrastających głównie z fascynacji pisarstwem historycznym Henryka Sienkiewicza i Józefa Ignacego Kraszewskiego (Olszewska 2009, s. 324), wypracowała jednak własny sposób budowania dyskursu historycznego (Olszewska 2009, s. 325 i nast.). Pomimo przypisywanego jej powinowactwa z pisarstwem XIX-wiecznym nie wiązała wątków historycznych z atrakcyjnymi wątkami przygodowymi i mocno ograniczyła wątki miłosne. Pisarka, obdarzona zmysłem malarskim, uczyniła swe utwory barwnym freskiem dziejowym, dzięki czemu odległe w czasie wydarzenia na kartach jej powieści nabierały blasku i wyrazistości, czego potwierdzeniem jest przede wszystkim obszerny cykl poświęcony średniowiecznym wyprawom krzyżowym - pt. Krzyżowcy (Bóg tak chce, Fides Graca, Wieża trzech sióstr, Jerozolima wyzwolona; 1935), Król trędowaty (1937) i zamykające całość Bez oręża (1937). Za kolejne ogniwa średniowiecznego cyklu, co prawda nieformalnie związane z „trylogią”, można uznać Bitwę pod Legnica (1930), Warnę (1938) oraz Puszkarza Orbano (1936). Szeregowo uporządkowane „średniowieczne" utwory Z. Kossak budują szeroką panoramę czasowo-przestrzenną od X w. aż po wiek XV.

Obok tego potężnego cyklu sytuują się jej XVI- i XVII-wieczne powieści, takie jak Beatum scelus (1924) - po latach ponownie podjęty wątek w Błogosławionej winie - Z miłości (1926), Trembowla (1939) i Suknia Dejaniry (1939). Pisarka osadziła je na fundamencie legend dziejowych, które pojawiły się w powyższym cyklu i pełniły tam ważną funkcję w strukturze powieści oraz jako nośnik nadrzędnego sensu. W Błogosławionej winie pisarka dokonała transformacji na fabułę powieściową „rzymskiej legendy” Mikołaja Sapiehy, noszącego przydomki Pius i Fundator - wojewody i senatora, fundatora kościołów i opiekuna klasztorów, żarliwego katolika i dobrego patrioty, wiernego królowi. Opo-

${ }^{2}$ Obszernie omówiłam te zagadnienia w: Olszewska 2009, s. 323-392 - rozdz. 4 (Filozofia krzyża. Zofii Kossak trudna lekcja historii, miłości i cierpienia). 
wiada legendowe dzieje wykradzenia przez niego z Rzymu cudownego obrazu Matki Boskiej Gregoriańskiej di Guadelupa, klątwy papieskiej, pokuty i darowania winy przez Urbana VIII w uznaniu dla odważnego wystąpienia Sapiehy na sejmie warszawskim i jego kategorycznego sprzeciwu wobec małżeństwa Władysława IV z protestantką w imię obrony jedności wiary katolickiej i kościoła w Rzeczypospolitej. Z miłości poświęcone zostało dziejom św. Stanisława Kostki, który uciekł z domu rodzinnego, aby wbrew woli ojca wstąpić do zakonu jezuitów i poświęcić się służbie Bogu. Portret św. Stanisława daleki jest jednak od hagiograficznych wizerunków. Z. Kossak wyeksponowała w tej postaci poczucie wewnętrznej wolności w imię powołania przez Boga. W Trembowli rzecz tyczy się wojny polsko-tureckiej. Trzej synowie Hieronima Kośmińskiego herbu Trzy Trąby - Wicek, Olek i Kostek - wyruszają na wojnę u boku Filipa Słotyły, który swym męstwem chce zmyć infamię nałożoną na brata. Tłem wydarzeń stała się wojna polsko-turecka, prowadzona przez Jana III Sobieskiego i Mahometa IV. Uwaga pisarki skupiła się wokół obrony tytułowej Trembowli, drugiej po Kamieńcu Podolskim twierdzy na Podolu, broniącej Rzeczpospolitą przed Turkami i Tatarami. Ducha do walki obrońcom zagrożonej twierdzy dodawała żona jednego z nich - Anna Dorota Chrzanowska. Zgodnie z przekazem legendowym to dzięki jej heroicznej postawie żołnierze, którzy chcieli się już poddać, wytrzymali dwa tygodnie do przybycia odsieczy Jana III Sobieskiego. Z kolei w Sukni Dejaniry, przekształcającej twórczo Legendę o św. Aleksym, pisarka wykorzystała relację ks. Podolca TJ, wychowawcy i spowiednika protagonisty Kaźmierza Korsaka, starościca głębockiego, traktującą o jego wyprawie pod Smoleńsk, zamianie w czasie bitwy sukmany szlacheckiej na chłopską, kainowej ranie zadanej przez ciotecznego brata Konstantego, zniknięciu Kaźmierza, jego powrocie do rodzinnego majątku jako chłopa pańszczyźnianego, długoletniej służbie na folwarku, milcząco znoszonym przez lata cierpieniu, upokorzeniu i zdobywaniu szacunku u współziomków - i w końcu o ujawnieniu w przedśmiertnej spowiedzi prawdziwej tożsamości.

Każdy z bohaterów tych utworów o charakterze historycznym w trakcie trwania opowieści zatraca swoje cechy indywidualne na rzecz ogólnych. Powoli urasta do rangi bohatera ponadczasowego, co oznacza, że teksty te można odczytać w kategoriach paraboli, a bohaterowie przybierają formę archetypiczną. Jan Trzynadlowski zwrócił uwagę, że w swych historycznych powieściach Z. Kossak „sytuuje kreślone przez siebie obrazy w starannie obranych realiach historycznych, wszakże historia tutaj [...] jest jedynie krajobrazem dla postaci bohaterów" (Trzynadlowski 1983, s. 54). W swych utworach pisarka prowadziła szczególny dialog „przeszłości z teraźniejszością” w rozumieniu Thomasa Carlyle’a, wykorzystując w tym celu potencjał estetyczny i religijny legendy, która, jak się okazuje, odgrywa dominującą rolę w jej pisarstwie, organizując strukturę dzieła, jak również określając jego wymowę ideową. Legendowe ujęcie tematu tworzy mocny fundament 
dla większości budowanych przez Z. Kossak opowieści, w tym także dla tych zebranych w interesującym nas tomie Ognisty wóz. A zatem, co należy podkreślić, utwory te, taktujące o relacjach Boga i człowieka, o wierze i świętości, wyrosły przede wszystkim z legend, mających swe źródło w wielowiekowej tradycji ustnej. Zgodnie z definicją ,legenda to opowieść o treści fantastycznej nasyconej pierwiastkami cudowności, niezwykłości, szczególnie z życia świętych, apostołów i męczenników zasłużonych w krzewieniu wiary chrześcijańskiej" (Sławiński 1976, s. 211-212). Wyraz legenda wywodzi się z języka średniowiecznych klasztorów, gdzie w czasie posiłków czytano utwory budujące i oznacza „rzecz przeznaczoną do czytania”, czy też „coś, co należy przeczytać” (Sławiński 1976, s. 211-212). W znaczeniu pierwotnym - węższym - legendy to opowieści religijne o życiu świętych, natomiast w szerszym są to baśnie, podania, opowieści ludowe, które traktują prawdę historyczną w sposób dość swobodny³. Świat baśni w odróżnieniu od legendy jest oderwany od rzeczywistości, a akcja dzieje się w nieokreślonym czasie, natomiast podanie opiera się na rzeczywistych wydarzeniach i zawiera elementy historii udokumentowanej źródłowo. Legenda i podanie opowiadają o przeszłości, przy czym głównym motywem legendy staje się opowieść o życiu wybitnej jednostki. Obok legend biograficznych pojawiły się również m.in. legendy miejsca, które opowiadają o wydarzeniach związanych z sanktuarium, miejscowością, górą itd. Pisarka w twórczy sposób przekształciła interesujące ją legendy, podania czy baśnie, wzbogacając je o różnego rodzaju wątki i motywy zapożyczone $\mathrm{z}$ innych gatunkowo dziel.

W tym miejscu warto zwrócić uwagę na jeszcze jeden, ważny fakt związany z obecnością legendy w twórczości Z. Kossak. Rzecz dotyczy przede wszystkim legendy biblijnej, która - według biblistów - jest jednym z gatunków literackich wykorzystywanych przez autorów Starego i Nowego Testamentu (Synowiec 2003, s. 252-272). Do legendarnej warstwy Starego Testamentu zaliczane są np. opowieści o Abrahamie z Księgi Rodzaju, Eliaszu z Pierwszej Księgi Królewskiej, Mojżeszu z Księgi Liczb, historie z Księgi Daniela lub o męczeństwie siedmiu braci z Drugiej Księgi Machabejskiej. Również na zasadzie legend funkcjonuje wiele opowieści związanych z miejscami kultu, czego przykładem jest opowieść o ołtarzu zbudowanym przez Gedeona z Księgi Sędziów lub o powstaniu Święta Namiotów z Drugiej Księgi Machabejskiej. Inspirująca dla formy i stylu pisarstwa Z. Kossak okazała się także legendarna warstwa Nowego Testamentu, a zwłaszcza barwnie napisana Ewangelia dzieciństwa Jezusa przez Mateusza i Łukasza. Obok dzieł kanonicznych istniały także apokryfy (w tym legendy apokryficzne) dostarczające wielu wątków dla dzieł literackich przybierających formę narracji apokryficznych. W konwencję twórczo przekształconej legendy

${ }^{3}$ Stefan Vrtel-Wierczyński (1937) wyróżnia trzy grupy legend: przyrodzone, nadprzyrodzone i historyczne. 
biblijnej Z. Kossak wpisała swą powojenną powieść poświęconą dziejom Abrahama pt. Przymierze (1951) (Bawół 2003, s. 83-98). Utwór ten, napisany na emigracji w Anglii, został przez pisarkę zaprojektowany jako wstęp do cyklu biblijnego, którego kolejnymi ogniwami miały być powieści o Mojżeszu oraz o niewoli babilońskiej, z centralną postacią proroka Daniela. Ponieważ w kraju ukazała się powieść Pustynia (1955) Jana Dobraczyńskiego, poświęcona Mojżeszowi, pisarka odstąpiła od tego pomysłu. Przymierze poświęcone zostało przede wszystkim kwestiom wiary, zawierzenia i wierności Bogu i w ostatecznym rozrachunku - nadziei wbrew otaczającym człowieka okolicznościom. Z. Kossak zdecydowanie wykroczyła tu poza schemat legendowy, pisząc głęboką opowieść o człowieku wierzącym.

Znaczenie, jakie w swej twórczości pisarka nadała legendzie od strony zarówno treści, jak i formy, jest również dobrze widoczne w napisanym przez nią i cieszącym się ogromną popularnością zbiorze legend hagiograficznych pt. Szaleńcy Boży (1929), budujących portrety różnych świętych w uwspółcześnionej wersji Złotej legendy Jakuba de Voragine'a ${ }^{4}$. Swe rozważania na temat świętości pisarka pogłębiła w odczycie pt. Beatyfikacja Skargi wygłoszonym na Skargowskim Kongresie Jubileuszowym (przedrukowanym potem na łamach „Prosto z Mostu”; Kossak 1936). Kreśląc postać Piotra Skargi, ,pysznego ze swej wiary” i dumnego z przynależności do Kościoła katolickiego, mówiła o nim nie tylko jako o wybitnym polityku, kaznodziei, proroku, ale także - przede wszystkim - jako o słudze Bożym, dowodząc, że nie było rozbieżności pomiędzy tym, co głosił, a tym, co czynił. Jak widać, pisarka świadomie podejmowała rozważania na temat świętości we współczesnym świecie nastawionym, jej zdaniem, na materializm i przeciętność, traktującym świętość jako odchylenie od normy. Zdaniem pisarki świętość, której człowiek nie powinien się lękać, lecz którą winien przyjmować jako dar, oznacza: „Miłować Boga i ludzi tak mocno, by to uczucie odbijało swoje piętno na każdej myśli, słowie i czynie" - i jak dalej pisała:

Święty to już jest po prostu pełny, doskonały katolik. Ideał wyznawcy, jaki stawia przed nami nasza wiara, jest tak trudny i wysoki, że osiągnięcie go staje się jednym ze świętością. Nie każdy święty musi być mistykiem i nosić stygmaty. W niebieskiej glorii chodzi wielu ludzi na pozór zwykłych i codziennych. Każdy z nich był jednak doskonałym katolikiem [wyróżn. M.J.O.]. A to już wystarczy (Kossak 1936, s. 2).

${ }^{4}$ W obręb tomu Szaleńcy Boży wchodzą: Legenda o świętym Jerzym; Pierwsze dary świętego Mikołaja; Opiekun Bożych stworzeń; Perly świętej Orszuli; Lew świętego Hieronima; Legenda sandomierska; Krzyż świętego Franciszka Ksawerego; Na Pustyni; Powódź w Krośnie; Legenda o świętym Andrzeju; Święci Jozafat i Barlaam; W puszczy; Szaleńcy Boży; Studzy nieużyteczni jesteśmy; Puszcza świętego Świrada; Pan czeka. 
Święci w ujęciu Z. Kossak są ludźmi „,z krwi i kości”, realizującymi swe posłannictwo w życiu codziennym, w rzeczach małych i zwyczajnych. To właśnie bohaterowie legend - owi „szaleńcy Boży” - jej zdaniem uświadamiają ludziom współczesnym, pochłoniętym troską o dobra materialne, goniącym za użyciem, cierpiącym na permanentne poczucie braku sensu, ,że świętość jest możliwa i człowiekowi do pełni szczęścia brakuje tak bardzo niewiele - tylko świętości” (Kamieńska 1982, s. 8). Według pisarki świętość nie jest czymś różnym od życia; wręcz przeciwnie, w pełni się w nie wpisuje. Historia świętości ma zatem dwa wymiary: ziemski i duchowy. Z. Kossak doceniła rolę rozwoju duchowego człowieka w jego drodze ku realizacji Bożych planów. Opisywana przez nią droga ku świętości staje się wędrówką w pełni świadomą, choć jednak zawsze okrytą Bożą tajemnicą. Ale to Stwórca - jej zdaniem - określa Swą relację z człowiekiem. Ten Boski dotyk, czy też wezwanie, jest tym, co odróżnia świętość od ludzkiej przeciętności i pychy, przy czym dla niej „,charakterystycznym jest owo tak znamienne u Świętych pragnienie ofiary z życia. Jak gdyby nie dowierzając sobie, czy dostatecznie miłują Boga, żądają tego ostatecznego sprawdzianu, dyplomu władzy, jakim po wszystkie wieki było ochocze przyjęcie cierpienia i śmierci" (Kossak 1936, s. 2). A zatem wszystko - zdaniem Z. Kossak - zależy od gotowości człowieka na wyrażenie posłuszeństwa wobec Bożych planów. $\mathrm{Z}$ tego powodu w jej utworach świętość nie sprowadza się do dewocji, tylko objawia się jako zjawisko przekraczające możliwości ludzkiego rozumienia. Okazuje się, że „świętość jest namiętnością wywołującą głębokie poruszenie, surowe starcia, krwawe walki, a życie świętych jest dramatem o wzruszających przejściach, bardziej ludzkim i silniejszym niż te, które mogą wymyślić powieściopisarze i pisarze sceniczni” (Calvet [b.d.], s. 125). Dlatego Z. Kossak tak pisała we Wstępie do Sukni Dejaniry o zagrożeniu, jakie dla materialistycznego, pragmatycznie nastawionego świata niesie świętość:

Świętość z natury swej odmienna jest od zwyczajności, a przeto razi. Świętość bywa często skandalem i zgorszeniem dla ludzi „trzeźwo myślących". [...] pozostaje obca światu. Świat toleruje pobłażliwie piękne legendy o Świętych, ale tylko, dopóki ci Święci nie zaczepiają jego podstawowych praw socjalno-ekonomicznych. Wtedy wypowiadają im walkę (Kossak 2002, s. 5).

Podsumowując te rozważania, należy stwierdzić, że pisarka w swych utworach na przestrzeni całej swej twórczości z dużym powodzeniem wykorzystała potencjał artystyczny zawarty w różnego rodzaju typach legend. Podstawowym typem legendy pozostały przy tym dla niej legendy biograficzne, które traktują o całym życiu bohatera lub też skupiają się na najważniejszych wydarzeniach z nim związanych. W zależności od tego, kto jest bohaterem opowieści, Z. Kossak 
mówiła o legendach świętych (hagiograficznych), wojowników (bohaterskich), władców czy polityków (politycznych), w każdym przypadku uznanych przez nią za ważne ze względu na przekonanie o wpływie sił nadprzyrodzonych na ludzkie losy (Sławiński 1976, s. 211-212). Legenda zakłada przecież przenikanie się dwóch światów: ludzkiego i pozaludzkiego; dopuszcza istnienie tego, co cudowne i niezwykłe, ponieważ „nic tak jak legenda nie potrafi cudowności tych spraw ocalić" (Kossak 1963; wstęp do wydania wydrukowany na okładce książki), i we właściwy dla siebie sposób tłumaczy to, co niewytłumaczalne, czyli ujawnia zjawiska, jakie stały się inspiracją do powstania legendy. Tak więc legenda - według Z. Kossak - dostarcza szczególnej wiedzy o świecie, ujawniając drugą, niematerialną stronę rzeczywistości, a przez to otwiera człowieka na Tajemnicę. Legenda pozwala na zbliżenie się odbiorcy do sacrum na tej zasadzie, że: „kto [...] głosił o świętych, głosił w istocie o Bogu” (Stępień 2003, s. 159). Dlatego spotkanie człowieka ze Stwórcą we wszystkich utworach autorki Krzyżowców przybiera ów szczególny, legendowy kształt. Jednocześnie Z. Kossak miała świadomość, że opowieści legendowe, przekazywane ustnie z pokolenia na pokolenie,

mają zazwyczaj ten sam lub bardzo podobny świat uczuć, myśli i wyobrażeń; podlegają takim samym lub podobnym próbom, doświadczeniom, prześladowaniom; uczestniczą w takich samych lub podobnych zdarzeniach i przypadkach; ześrodkowują w swych osobach najogólniejsze cnoty chrześcijańskie (Vrtel-Wierczyński 1937, s. 7).

Jednakże na przestrzeni lat legendy ulegały pewnej ewolucji, w wyniku czego zmieniał się ich sposób oddziaływania na odbiorców pochodzących z różnych epok, dlatego

im bardziej opiewane osoby i zdarzenia oddalały się w czasie, im głębiej zasuwała się w przeszłość bezpośrednia o nich pamięć, tym silniej zaczynała działać wyobraźnia, która nie zna żadnych granic ani w czasie, ani w przestrzeni, żadnych niemożliwości ani nieprawdopodobieństw (Vrtel-Wierczyński 1937, s. 5).

W ten sposób te różnego typu twórczo przetworzone tradycyjne wątki legendowe z powodzeniem mogły stać się tworzywem poetyckim i dać podstawę do utworów o wysokim poziomie artystycznym. Dlatego z tradycją legendy

nie zrywa też [...] literatura najnowsza, która w epoce - zda się - najmniej harmonizującej z nastrojem i duchem legendy, a może właśnie na mocy prawa kontrastu, niejednokrotnie ulega jej urokowi i z wielkim nieraz powodzeniem odtwarza dawne, średniowieczne opowieści religijne (Vrtel-Wierczyński 1937, s. 13). 
To obszerne, ale konieczne dla udokumentowania stwierdzenia, że interesujący nas tom Ognisty wóz realizuje charakterystyczne dla twórczości Z. Kossak cechy pisarstwa wpisującego się w paradygmat chrześcijański. Zwłaszcza na przykładzie rozpoczynających tom opowiadań: Widzę Go!, Ognisty wóz i Mędrcy świata - z zamierzonego, ale niezrealizowanego przez Z. Kossak cyklu biblijnego (Vrtel-Wierczyński 1937, s. 83) - doskonale widać, że Biblia, chociaż jest dziełem w wymiarze teologicznym, ma również wymiar antropologiczny i literacki. Powstała przecież w określonym czasie i kulturze, co wpływa na specyficzny typ lektury nie tylko samej Biblii (Bawół 2016, s. 59-79), ale również utworów nią inspirowanych, przyjmujących formę narracji apokryficznej (Jankowska 2011). Dlatego przy lekturze tych utworów „istotna jest pewna forma wtajemniczenia - przede wszystkim w kanon, ale także w specyfikę i reguły rozumowania. Apokryf można czytać jedynie jako anegdotę, niemniej jednak lektura naiwna, dosłowna jest tu znacznie mniej prawdopodobna niż w przypadku paraboli” (Michalski 2003, s. 170). Apokryf nie odnosi się do całej Biblii, tylko do wybranych jej fragmentów, konkretnych wydarzeń i postaci. Nierzadko Pismo św. okazuje się tekstem ukrytym, którego obecności trzeba się dopiero domyślać. Oznacza to, że kanon biblijny nie musi zawsze zajmować miejsca uprzywilejowanego. W tym przypadku lektura uwzględniająca intertekstualność tekstu okazuje się prymarna wobec lektury literalnej. Cecha narracji apokryficznej, jaką jest transpozycyjność, pozwala na wprowadzenie do tekstu współczesnej perspektywy. Tym samym następuje uaktualnienie kanonu, co czyni świat przedstawiony apokryfu współczesnym, jak również uniwersalnym ze względu na łączone odległe perspektywy, co z kolei umożliwia ujawnienie rysu parabolicznego prezentowanej historii. Narracja apokryficzna, uznająca zamknięcie kanonu biblijnego, odnosi się do niego intertekstualnie.

W tym przypadku ważna okazuje się nie tyle repetycja, ile interpretacja. Tak więc narracje apokryficzne, co dotyczy także tekstów z Ognistego wozu, komentują, naśladują i krytykują kanon Biblii. Człowiek w trakcie lektury zbliża się w ten sposób do Tajemnicy, a siła jego wiary opiera się na mocy Bożej, którą jest Objawienie. W ostatecznym rozrachunku to Stwórca nadaje ton temu spotkaniu. Człowiek musi Mu odpowiedzieć, budując z Bogiem relację lub ją odrzucając. Ową siłą budującą tę więź jest miłość. Dlatego każdy z budowanych przez pisarkę dyskursów w tym tomie ma charakter religijny, co oznacza, że wykracza poza barwną anegdotę opowiadającą o losach całego szeregu postaci przewijających się przez omawiany tom.

Pierwszy tekst z Ognistego wozu, czyli Widzę go!, poświęcony został Balaamowi, prorokowi Mezopotamii, nazwanemu przez potomnych „Prorokiem wbrew sobie". Jego to Balak, król Moabu, poprosił, by przeklął Izraelitów w czasie ich powrotnej wędrówki z Egiptu do Kaananu. Pokonali oni Amorytów i Balak obawiał się, że przyszła kolej na jego kraj. Początkowo Balaam odmówił 
spotkania się z królem (z rozkazu Bożego), lecz za drugim razem wyraził na to zgodę. Kiedy jechał przez pustynię, rozważając nad błędem wiary Izraelitów i ich małością, i kiedy bliski bluźnierstwu wyrzekł się Boga, wtedy miał objawienie. Na jego drodze stanął anioł i zatrzymał jego oślicę Sahor. Ale zaślepiony gniewem Prorok niczego nie zauważył; wściekły zaczął okładać bezbronne zwierzę, a robił to tak mocno, że oślica spłynęła krwią. Wtedy to usłyszał głos skarżącej się na jego okrucieństwo Sahar. W tym momencie

wydawało się Balaamowi, że rozróżnia w sercu blasku postać męża w szatach czerwonych jak szaty tłoczących w prasie, o wzroku pełnym litości, zdającym się powtarzać wołanie oślicy: - Com ci uczynił, Balaamie?! Dlaczego mnie bijesz? Lecz ledwie dojrzane, zjawisko ginęło przesłonięte blaskiem. I patrzącego ogarnęła trwoga, jakiej nigdy w życiu nie doświadczył. Nie sądził dotąd, iż podobny lęk może przejąć serce ludzkie. Poznał, Kogo miał przed sobą. To On, Nienazwany, Wszechobecny, Niepojęty. Ten, co zbiegłemu kapłanowi, pasącemu owce teścia, ukazał się w gorejącym krzaku! To Ten, co suchą nogą wiódł swój lud przez morze! Pan światła i ciemności, życia i śmierci, nieba i ziemi - Anioł Jego oblicza, Dech Jego ucieleśniony, stał się Synowi Człowieczemu podobny, aby śmiertelny mógł ujrzeć to, co nieśmiertelne!... (Kossak 1963, s. 16-17).

Wtedy Balaam zrozumiał, że w obliczu Pana jest tylko „dymem, prochem, lichym robaczkiem" (Kossak 1963, s. 17). Pod wpływem odczuwanego timor Dei ,z głębokości lęku Balaam zapytał: «Co chcesz, Bym uczynił Panie?» i usłyszał taką odpowiedź: «Idź i mów, co ja ci każę»” (Kossak 1963, s. 17). Pełen pokory Prorok wypełnił wolę Boga. „Zamiast przekląć Izraelitów, pobłogosławił im trzy razy. Przepowiedział gwiazdę, która zaprowadzi trzech królów do Betlejem, wierząc, że ON pozostanie na wieki” (Kossak 1963, s. 22). Balaam zrozumiał wtedy, że wszystkie ludzkie czyny są bez znaczenia, wszystko rozpadnie się w proch, a trwałe i niezniszczalne są tylko słowa Boga, bo On jest wieczny. Balaam posiadł zatem naukę o Bogu prawdziwym. To od Niego samego pochodzi proroctwo o Mesjaszu.

Drugie z biblijnych opowiadań to tytułowy Ognisty wóz opowiadający o losach proroka Eliasza. Stał się on wzorem człowieka, który wybrał Boga i postawił Go na pierwszym miejscu w swym życiu. Prorok ten stał się dla współczesnych mu i potomnych wzorem żywej łączności z Bogiem i jednocześnie żarliwości dawania świadectwa o Bogu swym wiernym i rozmodlonym życiem. Człowiek żyjący w ten sposób będzie promieniował Bogiem na otoczenie. Dopiero na drugim miejscu sytuuje się podejmowane apostolstwo słowa, które powinno wypływać z rozmodlenia i żarliwej wierności Stwórcy. Tak więc nie było rozdźwięku pomiędzy słowami Eliasza a jego czynami. Siłą swej wiary pokonał on kapłanów boga Baala 
i Astarete, których kult wprowadzony został przez Jezabel, żonę króla Izraela Achaba: „Obrzędy ku czci tych bóstw były krwawe, bezwstydne, znieważające uczciwość i godność [...]" (Kossak 1963, s. 27) - a za ten grzech odstępstwa Bóg zesłał karę suszy. Wiara Eliasza sprawiła, że Bóg cofnął swój gniew i ,nagle błysk, przy którym słońce wydaje się szare, i huk ogłuszający, jak gdyby runęła ziemia. Grom wypadł z jasnego nieba, uderzył w ołtarz ofiarny! Co żyje pada na twarze" (Kossak 1963, s. 34). Wtedy to „Król Achab upadł na ziemię, korząc się przed Panem. W obliczu zebranych tłumów ślubuje mu wierność dozgonną" (Kossak 1963, s. 35). Jednak król nie dotrzymał obietnicy, a Jezabel wysłała wojsko, aby pojmało Eliasza. Ten jednak uszedł na pustynię Negreb, gdzie przebywał przez wiele lat i gdzie według legendy kruk przynosił mu pożywienie. Następnie prorok udał się do Damaszku. Wtedy to, odwołując go od pługa, powołał Elizeusza do służby Bogu i namaścił go na proroka.

Eliasz był tym, któremu dane było doświadczyć obecności Najwyższego, o czym tak opowiadał:

Posłyszałem słowa: „Wynijdź, a stań na górze przed Panem”. [...] Na koniec zmilkło wszystko, był tylko szelest wietrzyka cichego, i w tym powiewie był Pan... Straszliwy jest i potężny. Rozdzielił mocą swoją morza starł głowę smoków, zmiażdżył łeb Lewiatana, dał go na pokarm drapieżcom pustyni. Otworzył źródła i potoki. Jego są dnie, do niego należy noc. A oto, jak się uniżył, by mówić do lichego robaka ziemskiego... (Kossak 1963, s. 39).

Opowieść o Eliaszu kończy się sceną, w której Samotnika uniósł do nieba wóz ognisty, a na ziemię spadł jego płaszcz. I ,[...] choćby przetrząsnęli wnętrzności ziemi, nie znajdą śladu Samotnika. Należał on do tych, których ciało nie będzie pastwą robactwa ani obróci się w proch” (Kossak 1963, s. 42).

Kolejny tekst $\mathrm{z}$ tego tomu wykorzystuje twórczo biblijny dotyczy fragmentu Nowego Testamentu, który opowiada o drodze Trzech Króli do betlejemskiej stajenki w czasach, kiedy

nie zanosiło się na żadną zmianę biegu spraw ludzkich i wtedy, gdy sędziwy mag perski, dla wielkiej mądrości zwany Królem Światła - Malki-Or - zobaczył wzrokiem wewnętrznym, niezależnym od zmysłów, nieznaną gwiazdę jaśniejącą na niebie. Przedziwne zjawisko nie było zwidem sennym, nie było też niespodzianką. Raczej jutrzenką dnia oczekiwanego z dawna (Kossak 1963, s. 43).

Trzej magowie przebywają daleką drogę, aby ujrzeć wielkiego Mesyjasza. Zamiast potężnego króla znajdują w żłóbku niewinne, bezbronne dzieciątko. 
Spotkanie to nie przyniosło im jednak rozczarowania, tylko stało się doświadczeniem głębokiej wiary, bo jak mówi jeden z królów:

Krótko byliśmy przed Jego obliczem, lecz przez ten czas pojąłem - mówi Malki-Or - więcej niż przez całe życie moje. Nie wiem jeszcze, dlaczego Pan wziął na siebie postać ludzką ze wszystką jej nędzą i trwogą, ale czuję, że tak musiało być... Pojąłem też, że On nie przymusi nikogo gwałtem ani rządzić będzie siłą...” (Kossak 1963, s. 52).

Czy więc uda mu się zawładnąc światem - nie wiadomo; pozostała im tylko głęboka wiara, że „sprawiedliwość i pokój dadzą pocałunek sobie...” (Kossak 1963, s. 52).

Po tych trzech biblijnych opowiadaniach kolejne opowiadania $\mathrm{w}$ tomie nie odwołują się już bezpośrednio do fragmentów Pisma św. Pierwsze z tej serii opowiadań - Stupnik i kusiciel - jest opowieścią zbliżoną w swym kształcie do legendy hagiograficznej poświęconej sylwetce Szymona Słupnika, który - rozczarowany codziennością i małością grzesznych ludzi - postanowił przyjąć na siebie pokutę i resztę swego życia spędzić dobrowolnie zamurowany na słupie, skazany na łaskę i niełaskę pogody i ludzi. Przez wiele lat wychudła postać Szymona Słupnika wyraziście rysowała się na tle nieba, wpisując się w krajobraz Antiochii. Lata izolacji, bezruchu, cierpienia doprowadziły Słupnika do poczucia bezsensu i zwątpienia, co zrodziło w nim pokusę odejścia od wiary w Boga. Jednak trud Szymona zostaje nagrodzony i otrzymuje on Łaskę doświadczenia obecności Boga żywego. W Niedzielę Wielkanocną odczuwa ogromną radość ze zmartwychwstania Pana, co ogłasza całemu światu, entuzjastycznie wykrzykując: „Pan zmartwychwstał! Zmartwychwstał iście! Wiedziałem, a nie wiedziałem! Słyszałem, a nie pojmowałem! Teraz przewidziałem! Pan zmartwychwstał! Bracia! Zmartwychwstaniemy i my!” (Kossak 1963, s. 67). Szymon w tym momencie umiera jako człowiek szczęśliwy, któremu została objawiona Prawda.

Kolejny tekst - Legenda o Świętym Mikołaju z Pierśca - poświęcony został historii rzeźby tego świętego, otoczonej szczególną czcią przez okolicznych mieszkańców. Świątka ukradkiem, w tajemnicy przed ludźmi, wyrzeźbił kaleki, niezdarny pastuch - Mikoła. Tchnął on własną duszę w tę rzeźbę, która wydawała się nawet do niego podobna. Rzeźba okazała się cudowna i zaczęła w nocy świecić. Wtedy to kolegialnie uradzono ustawić ją w olszynie na rozstaju dróg. Jednak ,pastuchowi Mikole nie wyszła ta sprawa na dobre. Jakby go figura urzekła - ciągle pod nią siedział i na swojego patrona patrzył" (Kossak 1963, s. 76). Zaniedbał się w pracy, wychudł i zmarniał. Wydawało się, że to blask legendy odebrał mu barwę ciała $\mathrm{i}$ krwi, ponieważ w miarę jak rodzi się legenda o Mikołaju z Pierśca, jego twórca, pastuch Mikoła, przestaje się liczyć w oczach ludzkich, marnieje i w końcu niezauważony umiera w cieniu 
wznoszącej się nad nim figury świętego. Postać Mikoły odeszła w mroki niepamięci, natomiast figura św. Mikołaja stała nieporuszona przez całe lata, dopóki do wsi nie przyszli luteranie i nie wprowadzili swoich porządków, przymuszając mieszkańców wsi do wyznawania nowej wiary. Świątek jako jedyny nie poddawał się, dalej nocą siejąc swą poświatę. Luteranie starali się go bezskutecznie zniszczyć, wywieźli do dalekiego klasztoru, wrzucili z rozkazu możnowładcy do głębokiego parowu, potem porąbali go i cisnęli do Wisły, ale on za każdym razem w cudowny sposób powracał na swoje miejsce na rozstaju dróg i dalej świecił. W końcu w Pierścu wybudowano kościół i postawiono wysoko na ołtarzu okaleczonego świątka.

Odkąd Świętego obudowano murami - przestał świecić, czemu się nikt nie dziwi. Pan Bóg jest hojny, ale nie rozrzutny - nie lubi zbytku dla zbytku. Przed świętym Mikołajem palą się świece, teraz jeszcze i lampki elektryczne - to na co miałby sam świecić? Gdyby przyszła znów zła pora, że Śląsk zalęgną ciemności, począłby świecić na nowo, bo moc Boża nie wietrzeje (Kossak 1963, s. 85).

Dwa ostatnie opowiadania dotyczą XX w., a konkretnie czasów II wojny światowej. Pierwsze traktuje o wydarzeniach rozgrywających się w Warszawie zimą 1941 r. Jest to historia Weroniki (był to pseudonim żołnierski Z. Kossak), która wbrew zdrowemu rozsądkowi postanowiła ocalić „niedołężnie malowany” (Kossak 1963, s. 87) stary obraz Matki Boskiej Częstochowskiej, „wadliwy w rysunku, wymowny w spojrzeniu, poczerniały z wieku" (Kossak 1963, s. 95). Obraz ten Weronika zobaczyła przypadkowo na wystawie sklepu z dewocjonaliami w gmachu z napisem Res sacra miser. Malarz

mimo nieuctwa osiągnął siłę wyrazu. Nie umiał odtworzyć rysów, lecz oddał spojrzenie. Oczy na wpół przysłonięte powiekami, oczy spłakane, a pełne czułej litości. Po tych oczach poznałbyś Jasnogórską na końcu świata. Po tych oczach poznałbyś również, że artysta malował według Cudownego Wizerunku i że czynił to na klęczkach (Kossak 1963, s. 88).

I chociaż „pędzel jego był nieudolny, modlitwa skrzydlata” (Kossak 1963, s. 88). Niewątpliwie ten stary obraz był wyrazem głębokiej wiary i czci jego twórcy dla Matki Bożej. Aby go kupić, Weronika wydała wszystkie posiadane pieniądze. Suma była duża: 300 złotych - a sprzedawca nie chciał obniżyć ceny. Weronika zaniosła obraz do domu, a było to 1 września 1941 r., trzeciego roku okupacji - w czasie, wydawałoby się, całkowicie pozbawionym nadziei. Okazało się, że w wyniku nocnego nalotu sklep został całkowicie zniszczony. Weronika zrozumiała wtedy sens swojego postępowania. 
Jakżeż wszystko było teraz jasne, zrozumiałe! I pośpiech poprzedni, i ów trawiący niepokój. Stary Obraz Częstochowskiej mial być ocalony [wyróżn. M.J.O.]. Nieznany człowiek, który go niegdyś malował na klęczkach, uzyskał dla swego dzieła przywilej trwałości. Więc życzliwe moce od sześciu miesięcy zabiegały o ratunek, wołając: „Zabierz go! Zabierz!...” (Kossak 1963, s. 95).

Kiedy Weronika wróciła do domu, okazało się, że ludzie przerażeni bombardowaniem skupili się przed obrazem, szukając ratunku w modlitwie.

Całość tomu kończy opowiadanie Noc $i$ świt z końcowych dni powstania warszawskiego, kiedy to ludność cywilna zostaje wypędzona z miasta skazanego na zagładę. Główną bohaterką jest umierająca na gruźlicę kości zakonnica, Agnieszka od Baranka Bożego. Odczuwająca ogromne cierpienie kobieta cały swój ból i wszelkie związane z chorobą upokorzenia ofiarowała jako dar Chrystusowi, modląc się nieustająco za grzeszników. „Każdy nowy dzień cierpienia był przez nią ofiarowany za taką lub ową duszę, za tych lub tamtych grzeszników. Dorzucony najpokorniej do Męki Zbawiciela stawał się pociskiem niewolącym Niebo" (Kossak 1963, s. 96). Kiedy wraz z innymi siostrami musiała opuścić klasztor, widok zniszczonej do fundamentów Warszawy wydawał się potwierdzać bezsens świata pozbawionego Boga i miłosierdzia. Przerażone siostry pomimo wypowiadanych słów modlitwy ,nie czuły się ani czujne, ani trzeźwe, lecz rozstrojone i słabe" (Kossak 1963, s. 101). Z tej trudnej sytuacji zdawała sobie sprawę Matka Przeorysza, dlatego modliła się o moc Ducha św. dla siebie i swych współtowarzyszek. Postanowiła odmawiać różaniec, wierząc, że „w dobie pokusy różaniec jest lepszą tarczą niż najmędrsze słowa” (Kossak 1963, s. 101). „Ale i tarcza nie chroni, kiedy serce mdleje" (Kossak 1963, s. 101). Modlitwę kobiet, które „wszystkie są przemoczone i zziębnięte, a przed nimi nieskończenie długa noc", coraz bardziej tracące poczucie sensu, przerywa krzyk umierającej Agnieszki od Baranka Bożego. Na dnie rozpaczy i beznadziei ta cierpiąca od lat, umęczona chorobą kobieta $\mathrm{w}$ akcie jasnowidzenia doznaje Łaski objawiania mocy Bożej. Daje świadectwo, radośnie wołając:

Siostry! Ja Niebo widzę! Siostry! Ja do Nieba idę!... [... I I głos nabrzmiały trumfem, wołający uporczywie: - Ja Niebo widzę! Ja do Nieba idę... Cieszcie się ze mną, bo do nieba idę! Przytomna ściska dłonie towarzyszek, oczy utkwiła w jasność niewidzialną. I za przewodem umierającej siostry zdają się dostrzegać chwałę zgotowaną tym, co Boga miłują. Ciemność, gruzy, nieznana przyszłość - tracą swe znaczenie. Noc wygnania i klęski przemienia się w świt (Kossak 1963, s. 102).

Nie ma więc śmierci - jest Zmartwychwstanie. Chrześcijaństwo wbrew okrucieństwu historii okazuje się radosną nowiną. W zakończeniu tego opowia- 
dania, które staje się jednocześnie pointą dla całego tomu Ognisty wóz, promień Bożego Miłosierdzia rozświetla otaczające ludzi ciemności, dając im nadzieję. Wiara w Boga ma sens, o ile budowana jest na fundamencie miłości - miłości miłosiernej. Nadzieja chrześcijańska staje się dla pisarki najwyższą wartością.

Zagadnienia podejmowane przez Z. Kossak zarówno w Ognistym wozie, jak i we wcześniejszej twórczości miały uświadomić odbiorcom nie tylko historyczne korzenie współczesności, ale także - przede wszystkim - uniwersalność ludzkich problemów i zachowań. Bohaterowie Ognistego wozu, każdy na swój sposób, zostają poddani sprawdzianowi z wiary w Boga. Otrzymują dar Łaski słabości, o której traktuje Ewangelia, a myśl tę podnosi św. Paweł w Liście do Koryntian, pisząc, że „Wystarczy ci mojej Łaski. Moc bowiem w słabości się doskonali" (2 Kor 12,9). Bohaterowie Z. Kossak, co dotyczy ich wszystkich, dochodzą do Prawdy stopniowo, dojrzewając do niej dzięki cierpieniu i poniżeniu. To pokora czyni z nich ludzi silnej wiary i duchowego męstwa. Jak wcześniej autorka pisała w Sukni Dejaniry:

od silnych Ofiarnik Chrystus wymaga ofiary. Ofiara jest siłą, która gwałci Niebo, ofierze nie może się oprzeć sam Stwórca... [...] w dobrowolnym poniżeniu tkwi najwyższe poświęcenie. Bo wszystkie uczucia łatwiej w sobie złamać niż miłość własną i przyrodzone pragnienie godności (Kossak 2002, s. 195-196).

Z. Kossak jest pewna, że Bóg, zgodnie z mądrością Ewangelii, powołuje słabych, po czym powołanych przez Siebie uzbraja w duchowe męstwo, aby wytrwali w znoszeniu przeciwności losu. A zatem w opowiadania te wpisane zostało ważne doświadczenie kenozy; należy je uznać za nośnik głównego sensu tych tekstów, których ostatecznym bohaterem okazuje się Chrystus zmartwychwstały. Analiza poszczególnych opowiadań z tomu Ognisty wóz dowodzi, że teksty dotyczące historii z różnych epok łączy paraboliczny i archetypiczny charakter, co z powodzeniem można odnieść do całego dzieła pisarki. W tych krótkich narracjach jest to znakomicie uwidocznione.

A zatem w centrum swej twórczości autorka Sukni Dejaniry usytuowała „szaleńców Bożych”. Są nimi ci, którzy w swym życiu na pierwszym miejscu stawiają Boga, a zatem ci, przez których realizuje się Boże działanie w historii. Niejednokrotnie zostają oni poddani próbie wiary, jaką jest próba wierności Stwórcy i wyznawanym wartościom. W utwory Z. Kossak wpisane zostało szczególne doświadczenie religijne. Droga do zbawienia w świecie, w którym wzajemnie przenikają się dwa porządki - doczesny (ziemski, ludzki) i wieczny (metafizyczny, Boski) - prowadzi, według niej, przez bolesne doświadczenie grzechu. Oznacza to, że zgodnie z wyznawanym przez nią światopoglądem zło, związane z pozahistorycznymi właściwościami ludzkiego istnienia, uobecnia się w świecie przez człowieka skażonego grzechem pierworodnym. Pisarka nie 
pozbawia jednak człowieka, obdarzonego przez Stwórcę wolną wolą, prawa wyboru między dobrem a złem. Zdaje sobie sprawę, że człowiek, choć powinien wybierać dobro, najczęściej wybiera zło. We wszystkich swych utworach, a szczególnie wyraziście w Krzyżowcach, pisała o pułapce, w jaką wpada człowiek, który podąża drogą „,nieprawych”. Nic jednak nie zwalnia go z odpowiedzialności za własne czyny. Sumieniu pisarka nadała wymiar eschatologiczny. Otto Forst-Battaglia docenił budowany przez nią obraz powieściowy; podkreślał, że w tym czasie w literaturze polskiej „nikt drugi równie konsekwentnie, logicznie i przekonywająco, a przy tym z taką artystyczną doskonałością nie wyjaśnił idei o nieuchronnym wyborze między Bogiem a szatanem, między zbawieniem a doczesnością, między Tak a Nie" (Forst-Battaglia 1935, s. 100).

Duchowe oczyszczenie i odrodzenie można - zdaniem pisarki - osiągnąć przez cierpienie i pokorę, pomagające człowiekowi przezwyciężać naturalne skłonności do zła. Ukierunkowanie się na Boga daje mu nadzieję na ocalenie i zbawienie. „Nadzieje ziemskie upadają w obliczu zła, cierpienia, śmierci. Jedynie nadzieja chrześcijańska jest odpowiedzią na tajemnicę, jaka ostatecznie stanowi ludzkie życie" (Krajewski 2018, s. 27). We wstępie do Błogosławionej winy Z. Kossak pisała, że omnia revocanda ad divinam prudentiam - wszystko trzeba odnieść do Opatrzności Bożej. Nie oznacza to jednak apologii postawy kwietystycznej, czyli biernego, beznamiętnego stosunku do świata i spraw życiowych; człowiek powinien podjąć wysiłek pozwalający na przezwyciężanie zła w sobie. Opowiadania z tomu Ognisty wóz, osadzone w całokształcie twórczości Z. Kossak, pozwalają na wyciągnięcie bardziej ogólnego wniosku, dotyczącego rodzaju doświadczenia religijnego obecnego w jej twórczości o wymiarze teologicznym ${ }^{5}$. Mamy bowiem $\mathrm{w}$ tym przypadku do czynienia $\mathrm{z}$ teologią historii (Olszewska 2009, s. 366). Warto więc w tym kontekście zadać pytanie podstawowe o ważną treść i istotę obecnego w twórczości Zofii Kossak doświadczenia religijnego, a szczególnie o rolę doświadczenia religijnego o charakterze mistycznym, sprowadzającego się do kwestii, czy jest to ludzki wybór, czy też może objawienie Boga. „Św. Tomasz z Akwinu odróżnia wśród prawd wiary koniecznych do zbawienia takie, które można poznać drogą rozumu naturalnego, tj. revelabilia (np. istnienie Boga), oraz takie, które mogą być poznane wyłącznie w wyniku Objawienia (np. Trójca Święta)" (Gilson 1960, s. 22-33). Wydaje się, że w twórczości Z. Kossak pojawia się wskazany podział na revelata i revelabilia oraz obecna w myśli Kościoła rzymskokatolickiego koncepcja praobjawienia, „co jest widoczne w wypowiedziach Nergal Sara: «Stworzenie, jeśli szuka, odnajdzie trop Stworzyciela»” (Bawół 2003, s. 85) i „,czego rozum ludzki nie pojął,

${ }^{5}$ Obszernie na ten temat pisze w swym artykule D. Bawół (2003), jednocześnie zaznaczając, że „Pod względem egzegetycznym i dogmatycznym autorka nie wykracza poza tradycję wiary swojego Kościoła” (s. 95). 
Pan ci to objawił" (Bawół 2003, s. 91). To objawienie tajemnicy dobra i zła tajemnicy Boga i jego działania w myśl zasady, że „chwała Pana odzwierciedla się w czynach wyznawców" (cyt. za: Bawół 2003, s. 92), co pozostaje w zgodzie z tradycją biblijną - Z. Kossak uobecnia w losach swych „szaleńców Bożych”. $\mathrm{W}$ ich czynach objawia się tajemnica historii zbawienia. Tak więc „zobaczę Pana mojego, zatem będę żył. Nie jest śmierć końcem istnienia. Stworzony zostałem na obraz i podobieństwo Boże, a czyż może z Nieśmiertelnego pochodzić śmiertelne" (cyt. za: Bawół 2003, s. 95).

Według nauczania Kościoła rzymskokatolickiego do poznawania Boga dochodzi się zarówno w sposób naturalny, wynikający z kontemplacji stworzeń i otaczającego świata, jak i w sposób nadnaturalny, w wyniku objawienia. W utworach autorki Krzyżowców obecne są oba te sposoby. Za Ewą Szonert (1969, s. 8-9) można jeszcze dodać, że pisarka starała się uprawdopodobnić zachowania swych bohaterów, a szczególnie ich relacje z Bogiem, poprzez motywację psychologiczną. W jej utworach doświadczanie Boga „konkretyzuje się [...] dzięki próbie i procesowi dochodzenia do wiary i jej rozwoju, co dokonuje się poprzez coraz pełniejsze poznanie Boga i tajemnicy historii zbawienia” (Bawół 2003, s. 96).

W utworach Z. Kossak mamy zatem obecną pieczołowicie dokonaną rekonstrukcję historyczno-kulturowego tła przy wykorzystaniu dostępnej wiedzy historycznej, jak również pogłębioną refleksję na temat rozwoju drogi duchowej jej bohaterów, co łączy się ze wspomnianą już psychologizacją wizerunku postaci. W ten sposób jej teksty, bez względu na obszerność i czas powstania, zyskują walor uniwersalności i dzięki temu każdy z bohaterów, a zwłaszcza z tomu Ognisty wóz, staje się archetypem „wierzącego”. A to oznacza, że każdy z nich „ma wymiar uniwersalny, odpowiada każdemu człowiekowi, który chce nasłuchiwać głosu Boga i potrafi być Bogu posłuszny" (Chrostowski 1992, s. 23). Tak więc każdy z Kossakowych „szaleńców Bożych” staje się „,modelem życia przed Bogiem i z Bogiem" (Chrostowski 1992, s. 23). Bez względu na czas historyczny czytelnik, nawet ten, który nie doświadczył Bożej obecności, może - do czego dążyła pisarka-identyfikować się z tak skonstruowaną postacią, odnaleźć siebie w jej doświadczeniach, przeżyciach, emocjach, perypetiach życiowych. Wiara w Boga zawsze i niezachwianie ma dla Z. Kossak wartość nadrzędną, ocalającą i zbawczą. Chrześcijaństwo w świecie permanentnego kryzysu aksjologicznego, w którym ogłoszono ,śmierć Boga”, bez względu na okoliczności historyczne pozostanie dla niej najdoskonalszym systemem, jaki został stworzony. Horyzont religijny i aksjologiczny tych utworów został wyraźnie wyznaczony.

Z. Kossak za pomocą literatury chciała „wyrazić teksturę ludzkiej egzystencji” (Farrer 1948; cyt. za: Bawół 2016). Była zdania, że czytelnik po lekturze jej utworów powinien zdobyć umiejętność odróżnienia dobra od zła, osiągnąć pewność, co w życiu jest ważne, a co - nieistotne; co jest godne naśladowania, a co - potępienia; co winno trwać, a co - przeminąć. Kwestie artystyczne zostały 
w tych tekstach podporządkowane określonej ideologii, co niewątpliwie wpłynęło na sposób budowy świata przedstawionego i styl wypowiedzi nacechowany retoryką perswazji aksjologicznej. Z. Kossak była świadoma wszystkich ograniczeń twórczych, jakie niesie promowana przez nią postawa pisarska, jednak nigdy nie zmieniła zdania, że: „wartość książki nie zależy od tematu. [...] Można to określić w ten sposób: „dobra literatura to ta, która ukazuje nieskończoność i wielkość wszechświata, sens życia, celowość życia, które pobudza do walki ze złem, do przeciwstawienia się złu, która głosi wiarę w zwycięstwo dobra, żąda heroicznej, aktywnej postaci" (Kossak 1939, nr 1, s. 2). Pisarka konsekwentnie i stanowczo twierdziła, że „Moje książki i ja - to jedno. Cokolwiek pisałam, udolnie czy nieudolnie, było wyrazem mego przekonania i nie mogłam cofnąć żadnej z danych wypowiedzi. Sens życia i cel życia - hierarchia uczuć i obowiązków względem Boga i człowieka utrwalał się we mnie" (cyt. za: Żmigrodzka 2008). I choć - jak pisała - „trudno przypuszczać, by kiedykolwiek nadeszła «koniunktura»" na pisane przez nią opowieści, to mimo wszystko „prawdę należy mówić zawsze i w każdych okolicznościach. Prawda nie płowieje, prawda, choć nie bywa nigdy modna, w żadnym wypadku nie staje się przestarzałą. Prawda nie jątrzy, nawet kiedy rani. Gorycz prawdy działa zbawczo" (Kossak 2002, s. 7-8).

Pisarstwo Z. Kossak, wpisane w paradygmat chrześcijański, dalekie od kontestacji rzeczywistości i eksperymentów formalnych, zachowało ów wspomniany już charakter perswazji aksjologicznej. Na zakończenie powtórzmy raz jeszcze: mimo osadzenia w realnej historii różnych epok utwory Z. Kossak łączy ich paraboliczny i archetypiczny charakter.

\section{Bibliografia}

Bawół D. (2003), „Przymierze” Zofii Kossak jako apokryficzne dzieje Abrahama, „Pamiętnik Literacki” 2003, t. 94, nr 4, s. 83-98.

Bawół D. (2016), „Święta poezja” starożytnych Hebrajczyków. O literackiej lekturze Biblii, „Zagadnienia Rodzajów Literackich” LIX, z. 3.

Calvet J (b.d.), O twórczości i krytyce katolickiej, przeł. i przedm. opatrz. A. Górski, Poznań.

Chrostowski W. (1992), Bohaterowie wiary „, Starego Testamentu”, Warszawa.

Forst-Battaglia O. (1935), Katolickie piśmiennictwo w Polsce niepodległej, w: Udział twórczości katolickiej w dzisiejszej literaturze świata. Zbiorowy zarys monograficzny, przeł. J. Birkenmajer, t. 2, Kraków.

Farrer A. (1948), The Glass of Vision, London.

Gilson E. (1960), Tomizm. Wprowadzenie do filozofii św. Tomasza z Akwinu, przeł. J. Rybałt., Warszawa. 
Jankowska M. (2011), Narracje apokryficzne w kulturze współczesnej, Poznan.

Kamieńska A. (1982), Wstep, w: Legendy dominikańskie, tłum. i oprac. J. Salij, Poznań.

Kossak Z. (1936), Beatyfikacja Skargi, „Prosto z Mostu” nr 4 (20.09.1936).

Kossak Z. (1939), Stużba pisarza, ,Albertinum” nr 1.

Kossak Z. (1963), Wóz ognisty, Warszawa.

Kossak Z. (2002), Suknia Dejaniry. Powieść historyczna, Częstochowa.

Kossak Z. (2004), Nota wstępna, w: Chrześcijańskie posłannictwo Polski, przedruk za: „Niedziela” 2.05.2004, nr 18.

Krajewski K. (2018), Nadzieja, w: Wobec nadziei. Aksjologiczne problemy dramatu i teatru XX i XXI wieku, red. J. Michalczuk i ks. M. Lach, Lublin.

Michalski M. (2003), Strategia apokryficzna, w: Dyskurs, apokryf, parabola. Strategie filozofowania w prozie wspótczesnej, Gdańsk.

Olszewska M.J. (2009), Drogi nadziei. Polska proza historyczna z lat 1876 1939 wobec kryzysu kultury. Wybór, Warszawa.

Sławiński J. (red.) (1976), Legenda, w: Stownik terminów literackich, Wrocław.

Stępień P. (2003), Z literatury religijnej polskiego średniowiecza. Studia o czterech tekstach. Kazanie na dzień św. Katarzyny, Legenda o św. Aleksym, Lament świętokrzyski, Ottarz Jezusow, Warszawa.

Synowiec J.S. (2003), Gatunki literackie w „Starym Testamencie”, Kraków.

Szonert E. (1969), Bóg, człowiek, historia. O twórczości Zofii Kossak-Szatkowskiej, „Życie i Myśl” z. 2.

Trzynadlowski J. (1983), Literackie wizje historyczne Zofii Kossak (Teoretycznoliterackie refleksje), „Kultura - Oświata - Nauka” nr 5.

Udział twórczości katolickiej w dzisiejszej literaturze świata. Zbiorowy zarys monograficzny (1935), przeł. J. Birkenmajer, t. 2, Kraków.

Vrtel-Wierczyński S. (1937), Staropolska legenda o św. Aleksym. Na porównawczym tle literatur słowiańskich, Poznań.

Żmigrodzka M. (2008), Dawać świadectwo prawdzie, „Niedziela” nr 15.

\section{Streszczenie \\ W blasku legendy, czyli Ognisty wóz Zofii Kossak. Lektura w kontekście twórczości pisarki}

Na tom Ognisty wóz (1963) składa się siedem krótkich opowiadań: Widze go!, Ognisty wóz, Mędrcy świata, Stupnik i kusiciel, Legenda o św. Mikołaju $z$ Pierśca, Naglace wołanie, Noc i świt. Opowiadania te traktują o wydarzeniach dziejących się $\mathrm{w}$ różnym czasie $\mathrm{i} \mathrm{w}$ różnej przestrzeni, począwszy od powrotu Izraelitów do Kaananu, przez czas narodzin Chrystusa, wydarzania z V w., po 
lata okupacji niemieckiej w 1941 r. do października 1944 r. Złożyły się one na spójną myślową i ideową całość. Spotkanie bohaterów z Bogiem, tak jak i w innych utworach pisarki, przybiera szczególny kształt. Spotkanie to odbywa się w realnej przestrzeni, wśród zdarzeń codzienności. Jednak to Stwórca nadaje ton temu spotkaniu, objawiając moc swego Miłosierdzia. Bohaterowie opowiadan, poddani próbie wiary i wierności, spotykają się z Chrystusem Zmartwychwstałym, głosząc jego chwałę. Tym samym zostają włączeni w tajemnicę Zbawienia. Opowiadania $\mathrm{z}$ tego tomu realizują ideę pisarstwa dalekiego od kontestacji rzeczywistości i niezmiennie zachowującego charakter perswazji aksjologicznej oraz fundament teologiczny.

Słowa kluczowe: Bóg, Biblia, świętość, historia, legenda, apokryf, wiara, pokora

\section{Summary}

\section{In the splendor of the legend, or Ognisty wóz by Zofia Kossak. Reading in the context of the writer's work}

The volume entitled Ognisty Wóz (1963) consists of seven short stories: Widzę go!, Ognisty wóz, Mędrcy świata, Stupnik i kusiciel, Legenda o św. Mikołaju z Pierśca, Naglace wotanie, Noc iświt. These stories deal with events happening in different time and space, from the return of the Israelites to Kaanan through the time of Christ's birth, the events of the 5th century, the years of German occupation in 1941 to October 1944. They formed a coherent, thoughtful and ideological whole. The meeting of the heros of this texas with God, as in other writer's works, takes on a special shape. This meeting takes place in real space, among the events of everyday life. However, it is the Creator who sets the tone for this meeting, revealing the power of his mercy. The heroes of these stories, subjected to a test of faith and loyalty, meet with the Risen Christ, proclaiming his glory. Thus they are included in the mystery of Salvation. The stories from this volume realize the idea of writing far from the contestation of reality and invariably maintaining the character of axiological persuasion and the theological foundation.

Keywords: God, the Bible, holiness, history, legend, apocrypha, faith, humility 